\title{
Traditional use of medicinal plants in the boreal forest of Canada: review and perspectives
}

Yadav Uprety ${ }^{1}$, Hugo Asselin ${ }^{1 *}$, Archana Dhakal ${ }^{1,2}$ and Nancy Julien ${ }^{2}$

\begin{abstract}
Background: The boreal forest of Canada is home to several hundred thousands Aboriginal people who have been using medicinal plants in traditional health care systems for thousands of years. This knowledge, transmitted by oral tradition from generation to generation, has been eroding in recent decades due to rapid cultural change. Until now, published reviews about traditional uses of medicinal plants in boreal Canada have focused either on particular Aboriginal groups or on restricted regions. Here, we present a review of traditional uses of medicinal plants by the Aboriginal people of the entire Canadian boreal forest in order to provide comprehensive documentation, identify research gaps, and suggest perspectives for future research.

Methods: A review of the literature published in scientific journals, books, theses and reports.

Results: A total of 546 medicinal plant taxa used by the Aboriginal people of the Canadian boreal forest were reported in the reviewed literature. These plants were used to treat 28 disease and disorder categories, with the highest number of species being used for gastro-intestinal disorders, followed by musculoskeletal disorders. Herbs were the primary source of medicinal plants, followed by shrubs. The medicinal knowledge of Aboriginal peoples of the western Canadian boreal forest has been given considerably less attention by researchers. Canada is lacking comprehensive policy on harvesting, conservation and use of medicinal plants. This could be explained by the illusion of an infinite boreal forest, or by the fact that many boreal medicinal plant species are widely distributed.

Conclusion: To our knowledge, this review is the most comprehensive to date to reveal the rich traditional medicinal knowledge of Aboriginal peoples of the Canadian boreal forest. Future ethnobotanical research endeavours should focus on documenting the knowledge held by Aboriginal groups that have so far received less attention, particularly those of the western boreal forest. In addition, several critical issues need to be addressed regarding the legal, ethical and cultural aspects of the conservation of medicinal plant species and the protection of the associated traditional knowledge.
\end{abstract}

Keywords: Medicinal plants, traditional knowledge, boreal forest, Aboriginal people, Algonquian, Athapaskan, conservation, management, policy

\section{Background}

Medicinal plants have been used in traditional health care systems since prehistoric times and are still the most important health care source for the vast majority of the population around the world [e.g. [1-6]]. It is estimated that $70-80 \%$ of people worldwide rely on traditional herbal medicine to meet their primary health care needs $[7,8]$. Globally, millions of people rely on

\footnotetext{
* Correspondence: Hugo.Asselin@uqat.ca

${ }^{1}$ Canada Research Chair in Aboriginal Forestry, Université du Québec en Abitibi-Témiscamingue, 445, boulevard de I'Université, Rouyn-Noranda, Québec, J9X 5E4, Canada

Full list of author information is available at the end of the article
}

medicinal plants not only for primary health care, but also for income generation and livelihood improvement [8]. Annual sales of herbal-based medicines range between 7.5 billion US\$ and 108 billion US\$ worldwide, the latter number representing sales of processed medicines [9]. In Canada annual market sales of medicinal plants reached 400 million US\$ in 2001 [10], and are growing at a pace of $15 \%$ annually [11].

Through millennia of trial and error, indigenous people have gained substantial knowledge of medicinal plants which has been transmitted from generation to generation as part of oral traditions $[12,13]$. However,

\section{Biomed Central}


concerns are being raised about the loss of native knowledge and the possible extinction of medicinal plant resources due to disruptions to traditional ways of life induced by colonial forces [14-17]. Hence, proper documentation of traditional knowledge regarding plant use, along with conservation and sustainable management of key habitats, could contribute to safeguarding this heritage [18].

A few studies have attempted to review the use of medicinal plants by the Aboriginal people of Canada, but they focused either on particular Aboriginal groups [e.g. [19]], or on restricted regions [e.g. eastern Canada [20]]. Here we present a review of the traditional use of medicinal plants by the Aboriginal peoples of the Canadian boreal forest. Furthermore, we provide complementary information on conservation status of medicinal plant species, as well as on policies framing medicinal plant use and traditional knowledge. Finally, we identify gaps in knowledge, and suggest perspectives for future research.

\section{Canada's Aboriginal People and the Boreal Forest}

Sometimes called the land of much geography and little history [21], Canada is blessed with an immense forest endowment [22]. The circumboreal forest is the most extensive terrestrial biome in the world, encompassing some 14 million $\mathrm{km}^{2}$ and $32 \%$ of the Earth's forest cover. Thirty percent of this world resource is found in Canada, where it occupies 58\% of the nation's land area comprising seven boreal and taiga ecozones [23]. Canada's boreal ecozones cover 5.8 million $\mathrm{km}^{2}$, of which 4.3 million $\mathrm{km}^{2}$ are forested [24]. The boreal forest of Canada is a broad vegetation zone (Figure 1) that stretches from the northern Atlantic coast westward to the Rocky Mountains, across the southwestern Northwest Territories and Yukon. The southern edge borders the eastern hardwood forest, abuts the north shores of the Great Lakes, and in the west intergrades with the aspen parkland and prairie. The northern edge fades into the tundra.

According to the 2006 census [25], there were 1172 790 Aboriginal people in Canada (including First Nations, Metis and Inuit), representing ca. $4 \%$ of the total population. The proportion of Aboriginal people is much higher in the boreal zone [26], reaching more than $30 \%$ of the total population in several areas [27]. Aboriginal peoples of the Canadian boreal forest are part of two major linguistic groups [28]: the central and eastern boreal forest is home to peoples of the Algonquian linguistic group (Mi'kmaq, Malecite, Abenaki, Penobscot, Innu/Montagnais, Cree, Atikamekw, Algonquin/Anishinabe, Ojibwa/Anishinabe, Chippewa), whereas the northwestern boreal forest is home to peoples of the Athapaskan linguistic group (Chipewyan, Dene, Gwich'in, Sekani)i (Figure 1).

Canada's forests have long played an integral role in supporting the lives of Aboriginal people, meeting their physical, cultural, spiritual and material needs. Traditional knowledge related to medicinal plants has been instrumental in the survival and wellbeing of Aboriginal people for thousands of years [29]. Unfortunately, this type of knowledge has been seriously eroding over the past decades $[14,29]$ indicating challenges for restoration. The concept of Aboriginal forestry, increasingly used in recent years [30-33], provides a means to keep indigenous cultures healthy and connected to the land [34-36]. Aboriginal communities possess their own traditional knowledge that contributes to a broader understanding of native plant species, many of which have yet to be studied by "western" scientists.

\section{Methods}

We reviewed scientific studies published in journals, books, theses and reports. Pertinent literature was searched in different electronic databases (ISI Web of Science, MEDLINE, Science Direct, Scopus, and Google Scholar) using specific search terms such as "medicinal plants", "traditional", "Aboriginal OR First Nation OR Indigenous OR Indian", "boreal”, and "Canada". We do not claim to have included every existing information source about traditional uses of medicinal plants, but we rather chose to focus on information easily accessible to researchers (available on the internet or through interlibrary loan). We are aware that several Aboriginal communities have endeavoured to record their members' traditional knowledge related to medicinal plants over the last few decades. However, in most cases, this information has yet to be made available to outsiders.

We reviewed a total of 49 publications that provided information about the use of medicinal plant species to treat various ailments. We only used publications presenting first-hand ethnobotanical information. Previously published reviews were consulted but were not included in the analyses. A master list was produced, showing name(s), part(s) used, use(s), and reference(s) for each species (Additional file 1).

Although we focused our search on traditional medicinal practices of Aboriginal people living in the Canadian boreal forest, some of the inventoried plants are distributed partly or entirely outside the boreal forest (e. g., in the temperate forest or in arctic or alpine areas). Large-scale trade networks between different nations are known to have existed in the past [37], allowing boreal peoples to obtain plants from contiguous areas in exchange for other goods. 


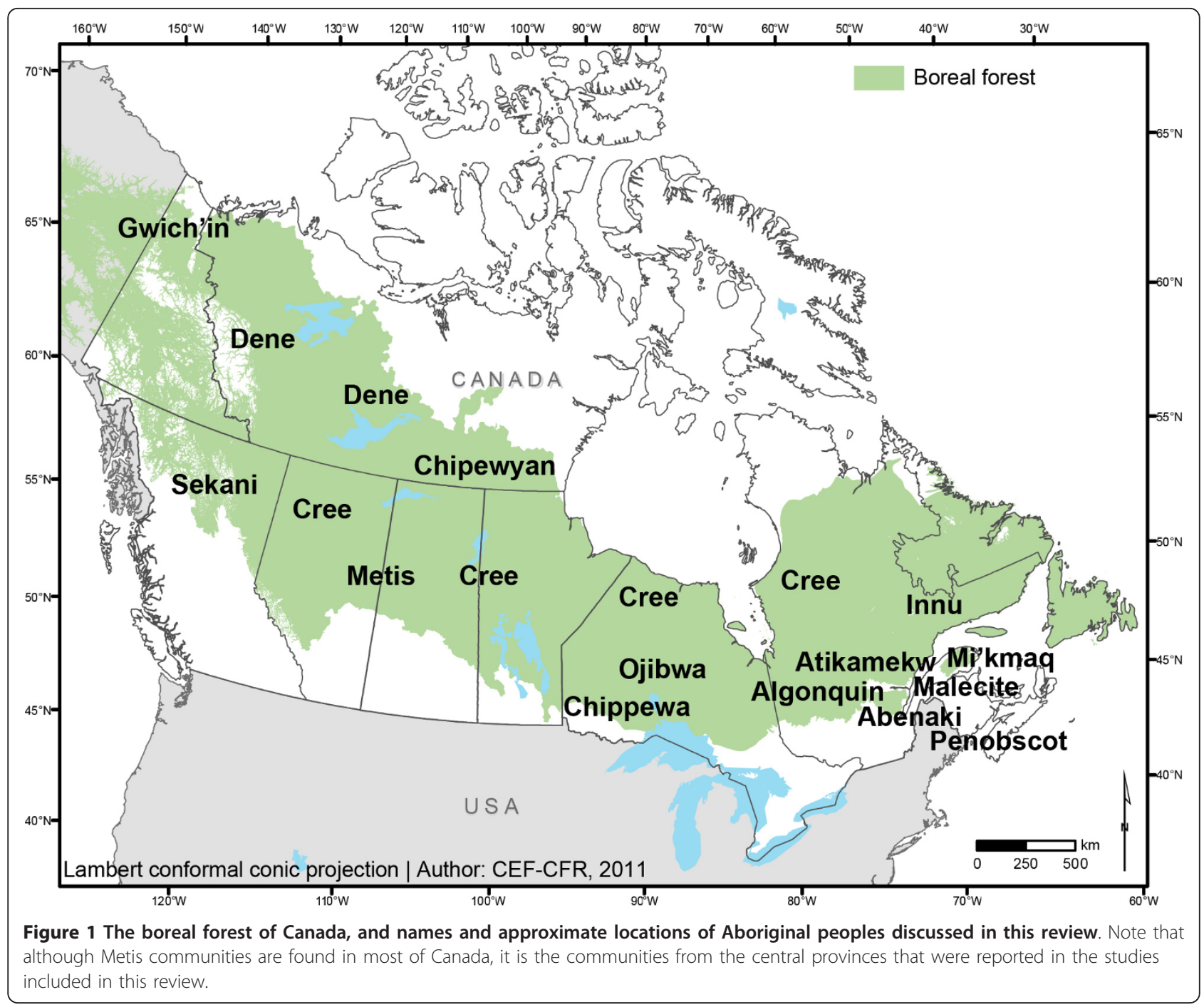

The precision of botanical identification in this review depended on that from original sources. Latin names and native status (native vs. introduced) were verified in the Plant Database of the United States Department of Agriculture, Natural Resources Conservation Service [38], the Plant Database of the Missouri Botanical Garden [39], the Flora of North America [40], and the Canadian Vascular Plants Database (VASCAN) [41]. Whenever available, subspecies (ssp.) and variety (var.) names are also provided. The currently accepted name is followed by synonyms, when provided in the source references. In some cases, only the genus was provided in the literature [e.g. [42-44]] and we did not attempt to refine the information to the species level.

The Aboriginal plant names mentioned in this review were taken textually from the original sources, whenever they were reported. Since North American Aboriginal cultures were based on oral tradition prior to European contact, various spellings exist for the same word. No selection was done and all variants are provided. Most Aboriginal languages are descriptive and thus the name given to a plant often refers to its appearance or function rather than to genetic uniqueness. Identical names are thus sometimes given to different species, or different names to the same species. To some extent, the approach shows similarities with the concept of plant functional traits [45].

Traditional plant uses are provided with the name of the Aboriginal group whenever the information was available, and the reference from which the information was retrieved. We followed the method proposed by Cook [46] to classify plants according to the different ailment categories they help to cure. However, in some cases Cook's [46] categories were not precise enough and plants were assigned to additional ailment categories. 


\section{Ethnomedicine of Boreal Canada}

Traditional medicine among the Aboriginal peoples of the Canadian boreal forest is based on oral tradition transmitted through several generations [13,47]. It is a cultural phenomenon, dynamic and adaptive, like language and other cultural manifestations [13]. The holistic approach of Aboriginal healing systems involves spirituality and intimate connection with the natural environment $[47,48]$. It also involves strong community networks of people who participate in the process of healing, and who can direct community members to people who have the knowledge to facilitate healing.

Vogel [49] compiled the historical context of Aboriginal peoples' medicinal culture and discussed shamanistic and spiritual aspects. Moerman [50-52] published some of the most complete ethnobotanical compilations for North America, including boreal Canada. Shemluck [53] provided a review of the medicinal uses of species from the Asteraceae family by North American Aboriginal people. Andre et al. [54] compiled the medicinal knowledge of Arctic and Subarctic indigenous people.

\section{Ethnomedicine of Eastern and Central Canada}

Assiniwi [55] and Erichsen-Brown [56] reported uses of medicinal plants by eastern North American Aboriginal people. Foster and Duke [57] published a useful field guide to the medicinal plants of central and eastern North America. Arnason et al. [20] reported on some 400 medicinal plants used in traditional health care systems by Aboriginal people of eastern Canada. Only for the Maritimes, 128 medicinal plant species were reported to be used by Chandler et al. [58]. Medicinal plants knowledge of Aboriginal people from the Maritimes has also been explored by several other researchers [43,48,59-65]. Youngken [44,66] studied the medicinal knowledge of several groups from the northeastern United States and Canada and Rousseau [67] worked with the Abenaki. Speck [63] reported on Algonquian peoples' knowledge, whereas Marie-Victorin [68] and Black [69] specifically worked with the Algonquin. Tantaquidgeon [70], Clément [71] and Laurendeau [72] explored Montagnais (Innu) knowledge, Raymond [73] worked with the Atikamekw, whereas Holmes [42], Strath [74], Jenkins [75], Beardsley [76], Grandi [77], Williams and Glover [78], Iserhoff et al. [79], Marshall [80,81], Fraser [82] and Leduc et al. [83] focused on Cree territory. The Ojibwa knowledge of medicinal plants has long been a subject of great attention and it has therefore contributed a lot to the ethnobotany literature of the Central boreal region [47,84-89]. Some of these studies were reviewed and compiled by Meeker et al. [19] who provided detailed information about 384 plants used by the Ojibwa ${ }^{\text {ii }}$. Davidson-Hunt et al. [90] provided identification, classification and nomenclature systems for plants used by the Ojibwa. Beresford-Kroeger [91] provided some information about traditional medicinal uses of tree species found in northeastern North America.

\section{Ethnomedicine of Western Canada}

Marles et al. [13] described the traditional use of plants by Cree, Dene, and Métis peoples of Manitoba, Saskatchewan, and Alberta. This study also partly covered eastern Canada, and it is the only one to cover Métis medicinal culture. Marles [92] also worked with the Chipewyan of northern Saskatchewan. Siegfried [93] documented the ethnomedicinal knowledge of the Alberta Cree. Leighton [94,95] and Clavelle [96] studied the Crees of Saskatchewan and Smith [97] reported on medicinal plant uses by the Sekani of British Columbia. Studies were also conducted with First Nations from the Dene group in the western boreal region: the Fisherman Lake Slave [98] the Prophet River First Nation [17], the Gwich'in $[99,100]$ and the Dogrib [101].

\section{Taxonomic Diversity, Growth habit and Parts Used}

We report on a total of 546 medicinal plant taxa used by Aboriginal peoples of the Canadian boreal forest (Additional file 1). Although most information was available at the species or even subspecies level, sometimes only the genera was provided. Among the most commonly used plants were: Abies balsamea (L.) Mill., Achillea millefolium L., Acorus calamus L., Aralia nudicaulis L., Betula papyrifera Marsh., Cornus sericea L., Heracleum maximum Bartram, Juniperus communis L., Larix laricina (Du Roi) K. Koch, Menta arvensis L., Nuphar lutea (L.) Sm, Picea glauca (Moench) Voss, Picea mariana (Mill.) BSP, Populus balsamifera L., Populus tremuloides Michx, Rhododendron groenlandicum (Oeder) K.A. Kron \& W.S. Judd., Salix sp., Sorbus americana Marsh, and Thuja occidentalis L. Angiosperms were predominant, with 474 taxa belonging to 90 families, followed by Pteridophytes (21 taxa from 5 families), Gymnosperms (21 taxa from 3 families), Fungi (13 taxa from 7 families), Lichens (11 taxa from 4 families), and Bryophytes (6 taxa from 2 families) (Figure 2). Well represented Angiosperm families were Asteraceae (62 species), Rosaceae (48), Liliaceae (21), Ericaceae (18), Betulaceae (18), Caprifoliaceae (18), Ranunculaceae (16), Salicaceae (16), Polygonaceae (15) and Lamiaceae (13). The prevailing growth habit (sensu [38]) of angiosperms medicinal plant taxa was herb (307 species), most likely because they are more abundant (Figure 3). The more abundant a plant is, the more likely it is to be used. The next dominant growth habit of angiosperm taxa was shrub (86), followed by tree (69) 


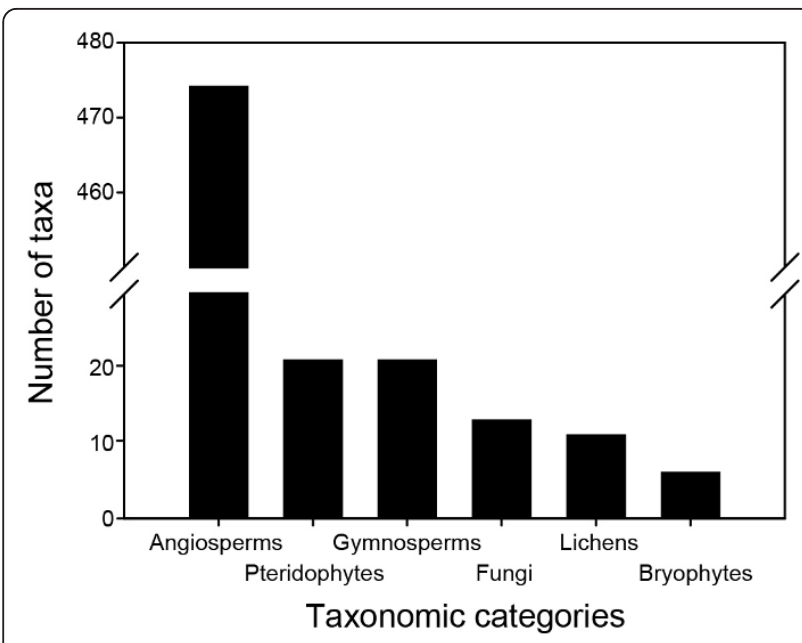

Figure 2 Frequency of medicinal plant taxa in major taxonomic categories

and vine (12). Of the 21 gymnosperm taxa, 19 were trees and 2 were shrubs. All dominant species of angiosperms and gymnosperms of the boreal forest were being used as medicinal plants. Furthermore, forty-nine introduced species were part of the native pharmacopoeia (Additional file 1).

Almost all plant parts were used to prepare different remedies: roots, rhizomes, stem, bark, leaves, flowers, fruits, young shoots, and whole plants (Additional file 1 ). The most frequently used plant parts were roots, followed by leaves, whole plants, fruits, and rhizomes.

\section{Ailments Treated and Preparation Methods}

A total of 28 major ailment categories were treated with medicinal plants (Table 1). Gastro-intestinal disorders, musculoskeletal disorders, cold, cough and sore throat,

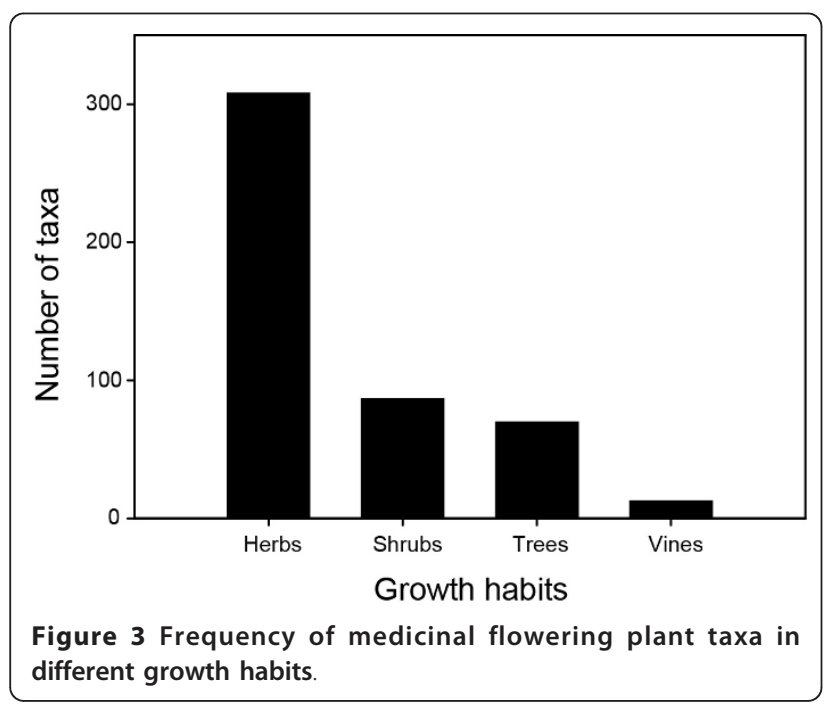

Table 1 Major ailment categories and taxa reported.

\begin{tabular}{|c|c|c|}
\hline Ailment category & $\begin{array}{c}\text { Number of } \\
\text { taxa* }\end{array}$ & $\begin{array}{c}\text { Number of use } \\
\text { reports }\end{array}$ \\
\hline Blood system & 39 & 17 \\
\hline Circulatory system & 53 & 16 \\
\hline $\begin{array}{c}\text { Cold, cough and sore } \\
\text { throat }\end{array}$ & 130 & 19 \\
\hline Dermatological & 100 & 40 \\
\hline Diabetes & 42 & 7 \\
\hline Ear & 20 & 17 \\
\hline Fainting and fits & 18 & 9 \\
\hline Fever & 62 & 22 \\
\hline Gastro-intestinal system & 214 & 26 \\
\hline General & 89 & 26 \\
\hline Gynaecological & 85 & 20 \\
\hline Haemorrhages & 38 & 19 \\
\hline Hair & 14 & 7 \\
\hline Headache & 69 & 28 \\
\hline Injuries & 119 & 36 \\
\hline Mental & 18 & 9 \\
\hline Metabolic system & 20 & 11 \\
\hline Musculoskeletal system & 134 & 34 \\
\hline Nervous system & 31 & 12 \\
\hline Nutritional & 70 & 24 \\
\hline Odontological & 44 & 23 \\
\hline Ophthalmological & 57 & 27 \\
\hline Poisoning & 41 & 16 \\
\hline $\begin{array}{l}\text { Pregnancy/Birth/ } \\
\text { Puerperium }\end{array}$ & 83 & 22 \\
\hline Respiratory system & 118 & 32 \\
\hline Sexual dysfunction & 3 & 2 \\
\hline Urinary system & 109 & 33 \\
\hline Venereal & 28 & 14 \\
\hline
\end{tabular}

*Most taxa were reported in more than one ailment category (see Additional file 1).

injuries, respiratory system disorders, urinary system disorders, and dermatological infections were treated with the highest diversity of medicinal plant species (Table 1 , Additional file 2).

Preparation methods included paste, poultice, juice, decoction, infusion, and chewing the raw plant (Table 2, Additional file 1). The majority of formulations were prepared as decoction or infusion (Additional file 1). Some formulations were prepared using combinations of different plants, sometimes as many as 20 substances being combined in one remedy [47]. Some formulations also included animal organs or fat $[47,85,95]$. Proper selection of species, parts, as well as preparation and administration methods are all very important in traditional health care systems $[17,81]$. Medicinal plant use should be carried out under the supervision of a knowledgeable person [81], usually an elder [102], as some plants might be poisonous (even lethal, e.g., Cicuta, 
Table 2 Common forms of preparation methods for remedies made of medicinal plants.

\begin{tabular}{ll}
$\begin{array}{l}\text { Preparation } \\
\text { method }\end{array}$ & Description \\
\hline $\begin{array}{l}\text { Paste } \\
\text { Poultice }\end{array}$ & $\begin{array}{l}\text { Fresh plant parts are crushed to obtain a paste used externally or internally. } \\
\text { Plant parts are crushed to obtain a soft moist mass generally used externally to treat swellings, pain, inflamed or infected body } \\
\text { parts. } \\
\text { Juice }\end{array}$ \\
$\begin{array}{l}\text { Obtained by squeezing or crushing plant parts and filtering through cloth. Sometimes requires addition of freshwater or other } \\
\text { liquid for dilution. }\end{array}$ \\
$\begin{array}{l}\text { Obtained by crushing dried plant parts. } \\
\text { Chewing }\end{array}$ & $\begin{array}{l}\text { Fresh plant parts are chewed without prior transformation. } \\
\text { Infusion }\end{array}$ \\
Decoction & $\begin{array}{l}\text { One plant species can be used in conjunction. } \\
\text { Conjunction. }\end{array}$ \\
\hline
\end{tabular}

Taxus, Veratrum), or could cause adverse reactions when taken in combination with other plants or with western medicine.

In some Aboriginal medicinal cultures the various processes of healing are connected with ceremonies and rites $[47,70]$. Those who possess the secret cures sometimes think that if they disclose them too freely the herbs will lose their potency [63]. When a plant is collected, it is important to leave a small offering (tobacco, matches, tea, rifle or shotgun shells, money, sugar or a prayer) in place of what is taken $[17,20,99]$. This ritual shows respect for the plant and increases the healing power of the medicine [20]. The season of collection and proper storage conditions are considered important for the effectiveness of remedies. Plants are usually gathered in late summer or early fall, when fully developed $[47,58]$. In some instances the fertile and sterile plants are considered separately [47]. When bark is used, it is sometimes collected from the eastern side of the tree $[65,70]$. When roots are used, the healing power is deemed stronger in certain portions than in others [47]. Medicinal plants harvesting practices are integral to the healing process, and crucial for resource preservation.

\section{Phytochemical and Pharmacological Studies of Boreal Canadian Medicinal Plants}

The most frequent approach to species selection for phytochemical, pharmacological or antimicrobial analysis is by reviewing the ethnobotanical literature. This highlights the importance of such studies in western pharmacognosy. Phytochemical and pharmacological studies investigating medicinal properties of North American plant species used to be lacking [20]. However, there was a marked increase in such studies in recent years, pinpointing the active principles of many plants used by Aboriginal peoples of Canada [12]. Examples of such studies are: Chandler and Hooper [103], Wat et al. [104], Chandler and Hooper [105], Hooper and Chandler [106,107], Bergeron et al. [108], Owen and Johns [109], Jones et al. [110], Lin et al. [111], McCune and Johns [112-114], Ficker et al. [115], BafiYeboa et al. [116], Spoor et al. [117], Awad et al. [118], Tsao and Liu [119], Webster et al. [120], Marles [92] and Martineau et al. [121].

At the species level, Chandler et al. [122,123] highlighted the correspondence between traditional use and phytochemical and pharmacological properties of Achillea millefolium and Tanacetum vulgare, two of the most widely used medicinal plant species in boreal Canada (Additional file 1). Applequist and Moerman [124] also reviewed ethnobotany and bioactivity of Achillea millefolium. Dufour [125] and de Moor [126] respectively studied biological activity in Rhododendron groenlandicum and Abies balsamea. Saxena et al. [127] analyzed the antimicrobial activities of Rhus glabra, Kobaisy et al. [128] highlighted the antimycobacterial activity of Oplopanax horridus, Kitts et al. [129] and Vuksan and Sievenpiper [130] considered Panax quinquefolius, Murch et al. [131] Hypericum perforatum, Petzke et al. [132] Taxus canadensis, and Matsuo et al. [133] Caulophyllum thalictroides. Matsuura et al. [134] worked on Empetrum nigrum.

Several studies were conducted on the anti-diabetic properties of medicinal plants, as diabetes is a serious concern for Aboriginal people of Canada $[83,117,135-138]$. Most of the scientific research into the anti-diabetic properties of boreal medicinal plants has been done in partnership with Cree communities of northern Quebec.

\section{Conservation and Management of Medicinal Plants}

Conservation and management of traditional medicinal plants is an important issue worldwide, mostly in developing countries where medicinal plants are primary forest products for rural communities. The nature of the interactions between traditional practices and local ecosystems can be both positive and negative depending on 
use intensity, intent (for local/personal use or for commercial use) and magnitude of exploitation [139]. Plants should only be collected in such a manner that ensures their continued presence, both in specific collection locations and across the landscape [19]. One of the biggest threats to the survival of medicinal plant species is habitat loss due to infrastructure development, mining, forestry, oil and gas exploitation, and hydro power generation projects [19]. Because many plant species have medicinal properties, their conservation could foster the preservation of important habitats for other species of plants and wildlife.

Conservation and management of medicinal plants has been given less attention in Canada than elsewhere, although it has been discussed recently [19,140-143]. Some management issues have been raised related to non-timber forest products (NTFPs), but without special focus on medicinal plants $[144,145]$. The most serious threats to boreal plants are habitat loss and fragmentation, climate change, and invasive species [143]. It is not known whether overexploitation is an issue in boreal Canada, as it is in several countries worldwide [18]. According to Westfall and Glickman [140], there is no formal system of accounting for medicinal plant harvesting in Canada, and thus little is known about which plants are being harvested, from where, and in what quantity. It could be too late to address conservation issues as the lack of a proper accounting system does not offer an up-to-date portrait of the status and scale of exploitation of medicinal plants. High pressure from the timber harvesting industry poses severe threats to medicinal plants in boreal Canada, especially to species associated to old-growth forests.

An integrated, collaborative approach for sustainable use, conservation and management of medicinal plants should be put into place and involve all stakeholders [146]. However, local peculiarities should be taken into account and the role of stakeholders might be different in different locations as the Aboriginal peoples of boreal Canada have different legal relationships with the federal and provincial governments. National level conservation policies do not necessarily apply within reserve boundaries. Furthermore, treaties and agreements between the governments and some First Nations have granted the latter different levels of control over natural resources [147].

Special care has to be given when attributing a legal protection status to a species because of over-harvesting by non Aboriginal people, as it will prevent Aboriginal people from using a resource they have been counting on for centuries. Furthermore, small-scale, aboriginal-led businesses based on in situ collection of medicinal plants provide interesting sustainable livelihood options. Special efforts have thus to be made to identify important plant collection areas [148]. Zoning tools could be especially helpful to decision making [149].

Of the 546 plant species included in this review, only six were listed as imperilled according to the Species at risk public registry [150]: Betula lenta, Cornus florida, Panax quinquefolius, Juglans cinerea, Solidago speciosa were endangered, whereas Aletris farinosa was threatened. Such a low percentage of species at risk could probably be explained by three factors: (1) most boreal plants have extensive distributions, (2) the boreal zone has been less impacted by human activities than more southern areas, and (3) the plants used by aboriginal people tend to be the more common ones.

\section{Challenges to Traditional Medicinal Plants Research}

Aboriginal people of Canada are worried that their knowledge could be stolen by profit-seeking pharmaceutical companies without acknowledging or involving communities [143], and without proper compensation being given in return. Concerns about the respect of intellectual property rights thus render most Aboriginal people reluctant to disclose their knowledge to outsiders [151], especially as legal protection is insufficient. This could explain why published ethnobotanical studies were somewhat less numerous in boreal Canada between the 1950s and 1970s (Figure 4). Informal discussions with Cree and Algonquin communities from Northern Quebec indeed revealed that Aboriginal people are cautious in reaction to misguided research practices by academics and government agencies. The historical background where Aboriginal people have suffered more inconveniences than they have benefited from European settlement is doubtless contributing to

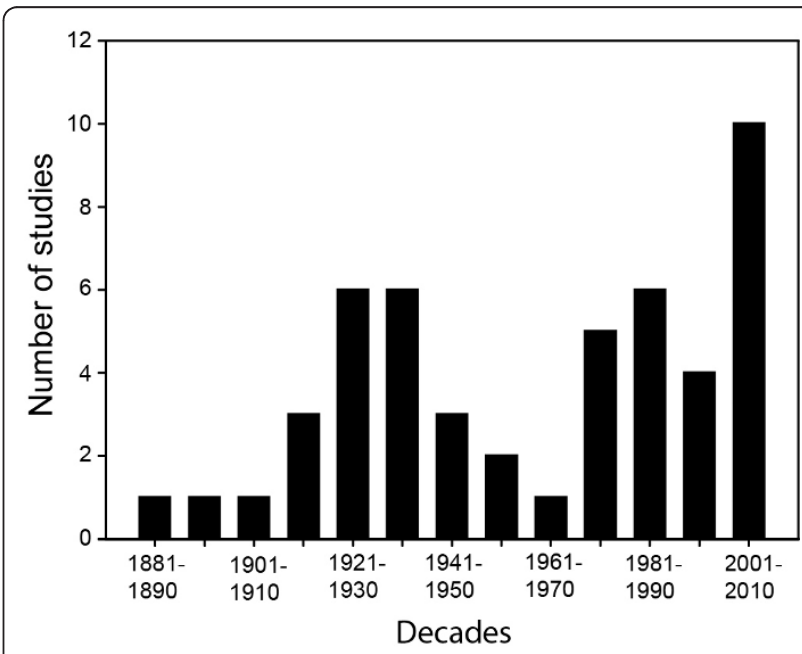

Figure 4 Number of studies included in this review for each decade between 1881 and 2010 
this generalized mistrust [21]. Also important is that land claims have not yet been settled for most Aboriginal communities and nations [152,153]. Aboriginal people would probably be more open to share their knowledge if they had more power in land governance [154].

In such conditions ethnobotanists face important challenges related to trust building and safeguarding traditional people's intellectual property rights. Nevertheless, a trustful environment can be favoured by considering the following ethical principles [after CNR [142]]:

- respect Aboriginal culture and protect sensitive and confidential information;

- ensure that knowledge ownership and project leadership resides with Aboriginal people;

- share benefits with communities;

- contribute to capacity building in Aboriginal communities;

- take into account and protect the interrelationship between environment, health and culture;

- obtain clear and informed consent from research participants, pay careful attention to ethical and legal issues, and obtain ethical approval of research protocols;

- respect Aboriginal and treaty rights.

\section{Policy and Institutional Framework Related to Medicinal Plants International Perspective}

Since its adoption in 1992, the United Nations Convention on Biological Diversity (CBD) has strived to implement its three major goals: conservation of biological diversity, sustainable use of its components, and a fair and equitable sharing of the benefits from the use of genetic resources [155]. Although medicinal plants were not explicitly on the agenda of the various CBD meetings, all three goals of the Convention are fully applicable to medicinal plant resources [156]. According to CBD's Article 8 (j): Traditional Knowledge, Innovations and Practices, signatories agree to

"respect, preserve and maintain knowledge, innovations and practices of indigenous and local communities embodying traditional lifestyles relevant for the conservation and sustainable use of biological diversity and promote their wider application with the approval and involvement of the holders of such knowledge, innovations and practices and encourage the equitable sharing of the benefits arising from the utilization of such knowledge innovations and practices".

Agenda 21 and Forest Principles adopted at the UN
Conference on Environment and Development (UNCED) identified forest products other than wood (also called non-timber forest products or NTFPs) as an important area requiring increased attention and as a source of environmentally-sound and sustainable development [157]. Since the Johannesburg Earth Summit in 2002, much attention has been given to the possibility of combining biodiversity conservation and poverty alleviation [158]. Via their legislations, countries are obliged to implement these various policy measures to ensure that traditional knowledge and intellectual property rights are respected [159]. The Conference of the Parties to the Convention on Biological Diversity held in Nagoya (Japan) in 2010 discussed the access and benefit sharing issues of sustainable use of biodiversity [160]. The Agreement on Trade Related Aspects of Intellectual Property Rights mandates countries to safeguard intellectual property rights [159]. The UN Declaration on the Rights of Indigenous Peoples, Article 24 includes provisions for use of resources (including medicinal plants) and rights over territories [161]:

\section{"Indigenous peoples have the right to their traditional medicines and to maintain their health practices, including the conservation of their vital medicinal plants, animals and minerals. Indigenous individuals also have the right to access, without any discrimina- tion, to all social and health services".}

The World Health Organization (WHO) has drafted several guidelines and passed resolutions for the integration of traditional health care systems and remedies into national health policies and regulations [8,162-165]. The specific guidelines on conservation of medicinal plants are provided in WHO et al. [165]. Organizations like WHO, the World Wildlife Fund (WWF), the World Conservation Union (IUCN), the UN Food and Agriculture Organization (FAO), the wildlife trade monitoring network-TRAFFIC, the International Development Research Centre (IDRC), and Plant Life International have been involved in the medicinal plants sector for a long time [see $[8,165,166]]$.

Various recommendations have been made on the use and conservation of medicinal plants, such as those associated with international conferences at Chiang Mai, Thailand, in 1988, and Bangalore, India, in 1998 and $2009[18,167]$. They included the need for co-ordinated conservation action, based on both in situ and ex situ strategies; inclusion of community and gender perspectives in the development of policies and programmes; the need for more information on medicinal plants trade; establishment of systems for inventorying and monitoring medicinal plants status; development of sustainable harvesting practices; encouragement of micro- 
enterprise development by indigenous and rural communities; and protection of traditional resources and intellectual property rights [18]. The recent International Healers' Conference on Promotion of Traditional Medicine for Sustainable Healthcare [167] called for the promotion of self-regulation of all traditional health professions, capacity building in local communities to develop biocultural protocols, integration of traditional medicine into national healthcare systems, and establishment of a Permanent Forum on Traditional Health Practices at the United Nations.

The regulation of existing markets by setting environmental standards for international trade is a traditional instrument advocated by international environmental policy [168]. Biodiversity conservation oriented trade policy measures are components of international agreements (e.g., the listing of species in CITES appendices and banning of certain species for trade on the international market). Likewise, the General Agreement on Tariffs and Trade (GATT) also regulates biodiversity trade and imposes certain restrictions on international trade of plant resources, including several species of medicinal plants. Existing guidelines for the sustainable collection of NTFPs provide useful models for medicinal plants, including the Forest Stewardship Council (FSC) sustainable forest management standard, the International Federation of Organic Agricultural Movements (IFOAM), and Fairtrade Labelling Organizations International (FLO) [2].

\section{National Perspective}

Comprehensive national policy, laws and regulations on traditional medicine do not exist in Canada [10]. Nevertheless, Aboriginal and treaty rights are protected by the constitution of Canada, and this is reflected in forest policy and forest management practices. Canada's National Forest Sector Strategy (1988, reviewed and revised in 1992, 1998, 2003 and 2008) included provisions for ensuring rights and participation of Aboriginal people and incorporating traditional knowledge, cultural values and practices in managing forest lands $[22,169,170]$. Involvement of Aboriginal people in developing non-timber forest products and the role they play in sustainable forest management have been recognized [22]. The economic development of NTFPs for diversification of the forest industry is one of the important aspects of sustainable management of Canada's forest [13]. Canada is also an active participant of multilateral and bilateral international treaties and conventions including Forest Principles and CBD adopted in 1992 in Rio, and CITES [22]; ensuring conservation and sustainable management of medicinal plants, as well as protection of indigenous knowledge. Canada has recently - although belatedly - ratified the
UN Declaration on the Rights of Indigenous Peoples that reaffirms the country's commitment to promoting and protecting the rights of Indigenous peoples and their resources [171].

Sustainable Forests: A Canadian Commitment published in 1992 [172] was signed by governments, industry, non-governmental organizations, Aboriginal people, and communities. It responded to international initiatives and commitments, including the UNCED and Agenda 21. The Canadian government has implemented the Species at Risk Act in 2002 to protect endangered and threatened species [173]. Equivalent legislations also exist at the provincial level [140].

The Natural Health Products Directorate of Health Canada is a governing body for the regulation of plant remedies. The Canadian policy on "Natural Health Products Regulations" includes herbal medicines among other things and was implemented in 2004 by the Natural Health Products Directorate $[174,175]$. The program has identified indigenous medicinal plants and Aboriginal contributions and approaches to alternative health care as priority research areas [141].

\section{Forest Certification and Aboriginal Medicinal Plants of Canada}

Forest certification provides important benefits to forest communities and certified forests are increasing in proportion since the beginning of the 1990's. Canada is leading the world in terms of total area of certified forest and proportion of managed forests that have been certified [176]. Certification standards mandate forest companies to protect biodiversity and Aboriginal culture. Specific criteria protect the rights of Aboriginal people, ensure preservation of Aboriginal resources, traditional knowledge and land, and compensation of Indigenous people for the use of their traditional knowledge in forest management [176]. These provisions provided by forest certification standards could benefit Aboriginal people by providing opportunities for protecting not only timber, but also non-timber forest values, including medicinal plants [177]. Interestingly, certification has proven equally, or even more effective than legislation to ensure protection of species, habitats and culture, as pressure from the market is often stronger than from governments.

\section{Trends, Gaps and Future Directions}

Ethnobotanical research in the Canadian boreal forest has so far focused on plant use by Aboriginal people from the eastern boreal zone. The Mi'kmaq and Malecite nations of the Maritimes are among the most studied groups [e.g. [43,48,60-65]], along with the Ojibwa/ Chippewa [e.g. [47,84-89]. In Quebec, Cree and Innu cultures have been given more attention [e.g. 
[42,70-83]]. The northwestern zone of the boreal forest has received less attention [but see [13,17,54,92-99].

After the 1960s, there has been a shift from ethnobotanical studies to phytochemical, antimicrobial and pharmacological studies. Notwithstanding the importance of phytochemical, antimicrobial and pharmacological studies, ethnobotanical efforts should continue, especially in areas and within nations that have received less attention so far, or for which publicly available material is scarce. For example, studies should be conducted in the northwestern Canadian boreal forest, notably with the Metis and with peoples of the Athapaskan language family, as well as with the Naskapi from northeastern Quebec. To diversify the scope of ethnobotanical studies, new methods should be adopted, for field work as well as for data analysis [e.g. [83,178-182]].

Studies are needed to determine if, for the same active principle and at the same dosage, the efficiency is different for traditional and western remedies. Possible interactions between medicinal plants and western medicine or between different species of medicinal plants also need to be investigated [183-185]. Studies are also needed in pharmacognosy, i.e. the standardization, authentication and study of natural drugs [186]. The utilization of animal products (alone or in combination with plants) to treat ailments has been given far less attention than medicinal plants, despite major potential [187].

From a governance point of view, gender-based or intergenerational knowledge differences related to medicinal plant use should be better documented. Studies are also needed to determine how traditional medicine could be given a larger place in modern health care systems [188-192].

Policy issues about traditional medicinal practices have not yet been properly addressed in Canada [10]. The recent adoption of the UN Declaration on the Rights of Indigenous People could provide incentives in this regard. Canada is also lagging behind in terms of regulations about conservation and management of medicinal plants. As suggested by Westfall and Glickman [140], Canada requires an enforceable policy that protects wild medicinal plants, effective monitoring system for commercial harvesting, and policy incentives for the cultivation of medicinal plants in order to reduce harvesting pressure of wild plants. However, harvesting medicinal plants from cultivated fields instead of natural forests might affect spiritual and ceremonial aspects, possibly with reduced medicinal effects [156].

\section{Conclusion}

Medicinal plants represent a significant contribution to human health and one of the most significant ways in which humans directly reap the benefits provided by biodiversity $[7,17]$. Use of medicinal plants by Aboriginal people from the Canadian boreal forest has a long history [11]. Here we reported on 546 medicinal plant species used in the traditional health care systems of Aboriginal people from the Canadian boreal forest. This is the most comprehensive review to date and it shows striking similarities between medicinal plant uses in different nations. Thus, by triangulation, it is probably still possible to document most of the knowledge, but research should continue, especially in areas or within nations that have received less attention.

\section{Endnotes}

i Only the names of the peoples mentioned in this review are provided. The Algonquian and Athapaskan language families include other peoples not listed here. The names are those that are currently in use and different names were sometimes provided in the older literature.

ii Anishinabe is the correct name for this people and it is how they refer to themselves. Ojibwa and Chippewa are names given to them by other tribes or by nonaboriginal people [see [19]]. The Algonquin also call themselves Anishinabe (or Anicinape) [33].

\section{Additional material}

Additional file 1: Medicinal plants used by the Aboriginal people of boreal Canada. Plants are sorted by scientific name. For each plant, family name, growth habit, vernacular name(s), part(s) used, use(s), and reference(s) are provided.

Additional file 2: Major disease categories and associated medicinal plants used by the Aboriginal people of boreal Canada.

\section{Acknowledgements}

Funding was provided by the Social Sciences and Humanities Research Council of Canada and by the Fonds institutionnel de recherche de I'Université du Québec en Abitibi-Témiscamingue. Thanks to Mélanie Desrochers (Centre for Forest Research, Université du Québec à Montréal) for helping with Figure 1 design. We are grateful to everyone that helped us find the literature used in this review. We also thank four anonymous reviewers for their constructive reviews.

\section{Author details}

${ }^{1}$ Canada Research Chair in Aboriginal Forestry, Université du Québec en Abitibi-Témiscamingue, 445, boulevard de I'Université, Rouyn-Noranda, Québec, J9X 5E4, Canada. 'Département des sciences de la santé, Université du Québec en Abitibi-Témiscamingue, 445, boulevard de l'Université, RouynNoranda, Québec, J9X 5E4, Canada.

\section{Authors' contributions}

$\mathrm{HA}$ and NJ designed the study. HA supervised the work. YU, HA and AD carried out the literature search. $\mathrm{YU}$ and $\mathrm{HA}$ analyzed the data and wrote the manuscript. All authors approved the final version of the manuscript.

\section{Competing interests}

The authors declare that they have no competing interests. 
Received: 30 May 2011 Accepted: 30 January 2012

Published: 30 January 2012

\section{References}

1. Iwu MM: Handbook of African medicinal plants London: CRC Press; 1993.

2. Leaman DJ: Sustainable wild collection of medicinal and aromatic plants. In Medicinal and Aromatic Plants. Edited by: Bogers RJ, Craker LE, Lange D. The Netherlands: Springer; 2006:97-107.

3. Carvalho AR: Popular use, chemical composition and trade of cerrado's medicinal plants (Goias, Brazil). Environ Dev Sustain 2004, 6:307-316.

4. Teklehaymanot T, Giday M: Ethnobotanical study of medicinal plants used by people in Zegie peninsula, northwestern Ethiopia. J Ethnobiol Ethnomed 2007, 3:12.

5. Heinrich M: Ethnobotany and its role in drug development. Phytother Res 2000, 14:479-488.

6. Uprety $Y$, Asselin H, Boon EK, Yadav S, Shrestha KK: Indigenous uses and bio-efficacy of medicinal plants in the Rasuwa district, Central Nepal. J Ethnobiol Ethnomed 2010, 6:3.

7. Farnsworth NR, Soejarto DD: Global importance of medicinal plants. In The Conservation of Medicinal Plants. Edited by: Akerele O, Heywood V, Synge H. Cambridge: Cambridge University Press; 1991:25-51.

8. WHO (World Health Organization): WHO traditional medicine strategy 20022005 Geneva: World Health Organization; 2002.

9. Scherr SJ, White A, Kaimowitz D: A new agenda for forest conservation and poverty reduction: making markets work for low-income producers Washington: Forest Trends, CIFOR; 2004 [http://www.cifor.cgiar.org/ publications/pdf_files/Books/A\%20New\%20Agenda.pdf].

10. WHO (World Health Organization): National policy on traditional medicine and regulation of herbal medicines. Report of WHO global survey Geneva: World Health Organization; 2005.

11. Lafrenière G, Chenier NM: Herb regulation in Canada: background and issues Ottawa: Government of Canada, Parliamentary Research Branch, MR-149E; 1997 [http://dsp-psd.pwgsc.gc.ca/Collection-R/LoPBdP/MR/mr149-e.htm].

12. Blouin $\mathrm{G}$ : Medicinal use of forest trees and shrubs by indigenous people of northeastern North America. Proceedings XII World Forestry Congress, Quebec City, Canada 2003.

13. Marles RJ, Clavelle C, Monteleone L, Tays N, Burns D: Aboriginal plant use in Canada's northwest boreal forest Vancouver: UBC Press; 2000.

14. Borins M: Native healing traditions must be protected and preserved for future generations. Can Med Assoc J 1995, 153(9):1356-1357.

15. Buenz EJ: Country development does not presuppose the loss of forest resources for traditional medicinal use. J Ethnopharmacol 2005, 100:118-123.

16. Uprety $Y$, Poudel RC, Asselin H, Boon E: Plant biodiversity and ethnobotany inside the projected impact area of the Upper Seti Hydropower Project, Western Nepal. Environ Dev Sustain 2011, 13:463-492.

17. Bannister K: Prophet river ethnobotany: A report on traditional plant knowledge and contemporary concerns of the Prophet River First Nation. British Columbia: Prophet River First Nation; 2006.

18. Hamilton A: Medicinal plants, conservation and livelihoods. Biodivers Conserv 2004, 13:1477-1517.

19. Meeker JE, Elias JE, Heim JA: Plants used by the Great Lakes Ojibwa Odanah, Wisconsin: Great Lakes Indian Fish and Wildlife Commission; 1993.

20. Arnason T, Hebda RJ, Johns T: Use of plants for food and medicine by Native Peoples of eastern Canada. Can J Bot 1981, 59(11):2189-2325.

21. Dickason OP, McNab DT: Canada's First Nations: A History of Founding Peoples From Earliest Times. 4 edition. Oxford University Press; 2009.

22. CCFM (Canadian Council of Forest Ministers): Canada's Forest Strategy for 2008 and Beyond Ottawa: Canadian Council of Forest Ministers; 2008.

23. Burton PJ, Messier C, Adamowicz WL, Kuuluvainen T: Sustainable management of Canada's boreal forest: Progress and prospects. Ecoscience 2006, 13(2):234-248.

24. Burton PJ, Messier C, Weetman GF, Prepas EE, Adamowicz WL, Tittler R: The current state of boreal forestry and the drive for change. In Towards Sustainable Management of the Boreal Forest. Edited by: Burton PJ, Messier C, Smith DW, Adamowicz WL. Ottawa: NRC Research Press; 2003:

25. Statistics Canada. [http://www.statcan.gc.ca]

26. Berkes F, Davidson-Hunt IJ: Biodiversity, traditional management systems, and cultural landscapes: Examples from the boreal forest of Canada. Inter Soc Sci J 2006, 58:35-47.

27. The Atlas of Canada. [http://atlas.nrcan.gc.ca].
28. Helm J, Sturtevant WC: In Handbook of North American Indians: Subarctic Volume 6. Smithsonian Institution Scholarly Press; 1982.

29. Turner NJ: Plantes aromatiques dans I'alimentation et la médecine des régions Nord-Ouest de l'Amérique du Nord. Phytothérapie 2009, 7:135-146

30. CCFM (Canadian Council of Forest Ministers): Defining Sustainable Forest Management in Canada: Criteria and Indicators Ottawa: Canadian Council of Forest Ministers; 2003.

31. Parsons R, Prest G: Aboriginal forestry in Canada. Forest Chron 2003, 79:779-784.

32. Wyatt S: First Nations, forest lands, and "aboriginal forestry" in Canada: From exclusion to comanagement and beyond. Can J Forest Res 2008, 38:171-180.

33. Saint-Arnaud M, Asselin H, Dubé C, Croteau Y, Papatie C: Developing criteria and indicators for Aboriginal forestry: mutual learning through collaborative research. In Changing the Culture of Forestry in Canada: Building Effective Institutions for Aboriginal Engagement in Sustainable Forest Management. Edited by: Stevenson MG, Natcher DC. Edmonton: Canadian Circumpolar Institute Press; 2009:85-105

34. In Seeing beyond the trees: the social dimensions of Aboriginal forest management. Edited by: Natcher DC. Ontario: Captus Press; 2008:

35. Berkes F, Chapin FS III: Conservation, community and livelihoods: Sustaining, renewing, and adapting cultural connections to the land. In Principles of Ecosystem Stewardship: Resilience-based Resource Management in a Changing World. Edited by: Chapin III FS, Kofinas GP, Folke C. New York: Springer-Verlag; 2009:.

36. In Changing the culture of forestry in Canada. Building effective institutions for Aboriginal engagement in sustainable forest management. Edited by: Stevenson MG, Natcher DC. Edmonton, Alberta: Circumpolar Institute Press; 2009:

37. Wright JV: In A history of the native people of Canada. Volume II. Ottawa: Canadian Museum of Civilizations; 1998

38. United States Department of Agriculture, Natural Resources Conservation Service, Plants Database. [http://plants.usda.gov]

39. Missouri Botanical Garden, Tropicos Database. [http://tropicos.org].

40. Flora of North America. [http://www.eFloras.org].

41. Database of Vascular Plants of Canada. [http://data.canadensys.net/ vascan/search/].

42. Holmes EM: Medicinal plants used by Cree Indians, Hudson's Bay territory. Pharm J Transactions 1884, 15:302-304.

43. Wallis WD: Medicines used by the Micmac Indians. Am Anthropol 1922 24:24-30.

44. Youngken HW: The drugs of the North American Indians. Am J Pharm 1924, 96:485-502.

45. Diaz S, Cabido M: Vive la différence: plant functional diversity matters to ecosystem processes. Trends Ecol Evol 2001, 16:646-655.

46. Cook FEM: Economic Botany Data Collection Standard Kew: Royal Botanic Gardens; 1995

47. Densmore F: Uses of plants by the Chippewa Indians. Forty-fourth Annual Report of the Bureau of American Ethnology 1926-1927 Washington: Government Printing Office; 1928, 275-397, (Reprint: Densmore F: How Indians use wild plants for food, medicine and crafts. New York: Dover Publishing Co; 1974).

48. Wallis WD, Wallis RS: The Malecite Indians of New Brunswick. Anthropological Series No. 40 Ottawa: National Museum of Canada; 1957.

49. Vogel VJ: American Indian medicine Norman, US: University of Oklahoma Press; 1970.

50. Moerman DE: Native American Ethnobotany Portland, Oregon: Tiber Press; 1998.

51. Moerman DE: Medicinal plants of Native America. Technical Reports, No. 19. Two volumes University of Michigan Museum of Anthropology, Ann Arbor: 1986.

52. Moerman DE: The medicinal flora of native North America. J Ethnopharmacol 1991, 31:1-42.

53. Shemluck M: Medicinal and other uses of the Compositae by Indians in the United States and Canada. J Ethnopharmacol 1982, 5(3):303-58.

54. Andre A, Karst A, Turner NJ: Arctic and Subarctic plants. In Handbook of North American Indians, volume 3, environment, origins and population. Edited by: Ubelaker DH, Stanford D, Smith B, Szathmary EJE. Washington DC: Smithsonian Institution; 2006:222-235. 
55. Assiniwi B: Survival in the bush Canada: The Copp Clark Publishing Company; 1972.

56. Erichsen-Brown C: Medicinal and other uses of North American Plants: A Historical Survey with Special Reference to the Eastern Indian Tribes New York: Dover Publication; 1979.

57. Foster S, Duke JA: A Field Guide to Medicinal Plants and Herbs of Eastern and Central North America New York: Houghton Mifflin Company; 2000.

58. Chandler RF, Freeman L, Hooper SN: Herbal remedies of the Maritime Indians. J Ethnopharmacol 1979, 1(1):49-68.

59. Speck FG, Dexter RW: Utilization of animals and plants by the Malecite Indians of New Brunswick. J Washington Acad Sci 1952, 42(1):1-7.

60. VanWart AF: The Indians of the maritime provinces, their diseases and native cures. Can Med Asso J 1948, 59:573-577.

61. Chandler RF: Vindication of Maritime Indian herbal remedies. J Ethnopharmacol 1983, 9(2-3):323-327.

62. Lacey L: Micmac Indian medicine: a traditional way of health Antigonish, Nova Scotia: Formac Limited; 1977.

63. Speck FG: Medicine practices of the northeastern Algonquians. Proceedings of International Congress of Americanists, Washington, DC 1917 1915, 303-321

64. Wallis WD, Wallis RS: The Micmac Indians of eastern Canada Minneapolis: University of Minnesota Press; 1955.

65. Mechling WH: The Malecite Indians, with notes on the Micmacs. Anthropologica 1959, 8:239-263.

66. Youngken HW: The drugs of the North American Indians II. Am J Pharm 1925, 97:257-271.

67. Rousseau J: Ethnobotanique abénakise. Arch Folklore 1947, 11:145-182.

68. Marie-Victorin F: Notes recueillies dans la région du Témiscamingue. Nat can 1919, 45:163-169.

69. Black MJ: Algonquin ethnobotany: an interpretation of Aboriginal adaptation in southwestern Quebec. National Museum of Man Mercury Series Ottawa: National Museums of Canada; 1980.

70. Tantaquidgeon G: Notes on the origin and uses of plants of the Lake St. John Montagnais. J Am Folklore 1932, 45:265-267.

71. Clément D: L'ethnobotanique montagnaise de Mingan Quebec City: Université Laval, Centre d'études nordiques, Collection Nordicana no. 53; 1990.

72. Laurendeau G: Consultations des entretiens sur l'occupation et l'utilisation du territoire (CAM) et autres activités ethnographiques menées dans la communauté ilnue de Mashteuiatsh (Pointe-Bleue) Rapport de recherche, Conseil des Montagnais du Lac-Saint-Jean; 2008.

73. Raymond M: Notes ethnobotaniques sur les Têtes-de-Boule de Manouan. Contribution Inst. Bot. Univ. Montreal; 1945:55:113-134.

74. Strath R: Materia medica: Pharmacy and therapeutics of the Cree Indians of the Hudson Bay territory. St Paul Med J 1903, 735-746.

75. Jenkins WH: Notes on the hunting economy of the Abitibi Indians. Catholic University of America. Anthropological Series 1939, 9:1-31.

76. Beardsley G: Notes on Cree medicines, based on a collection made by I. Cowie in 1892. Mich Acad Sci Arts Lett 1939, 28:483-496.

77. Grandi S: Social and health implications of plant remedies of the James Bay Cree for symptoms of type 2 diabetes mellitus. MSc thesis McGill University, Montreal, Canada; 2006.

78. In Andrew Graham's observations on Hudson's Bay 1767-91. Edited by: Williams G, Glover R. London, UK: The Hudson's Bay Record Society; 1969:

79. Iserhoff J, Sam M, Pachano M, Mattew S, Shem M, Pepabino L, Matthew E: Traditional Indian recipes from Fort George, Quebec. Cobalt, Ontario: Highway Book Shop; 1971.

80. Marshall S: Healing ourselves, helping ourselves: The medicinal use of plants and animals by the people of Waskaganish. Quebec: Cree Regional Authority; 1989.

81. Marshall S: The gift of healing: health problems and their treatments Chisasibi, Quebec: The Cree Board of Health and Social Services of James Bay; 2006.

82. Fraser MH: Ethnobotanical investigation of plants used for the treatment of type 2 diabetes by two Cree communities in Quebec: Quantitative comparisons and antioxidant evaluation. Master thesis Department of Plant Science, McGill University, Quebec, Canada; 2006.

83. Leduc C, Coonishish J, Haddad P, Cuerrier A: Plants used by the Cree Nations of Eeyou Istchee (Quebec, Canada) for the treatment of diabetes: A novel approach in quantitative ethnobotany. $J$ Ethnopharmacol 2006, 105:55-63.
84. Hoffman WJ: The Mide'wiwin: grand medicine society of the Ojibway. 2005 edition. Honolulu, Hawaii: University Press of the Pacific; 1891.

85. Gilmore MR: Some Chippewa uses of plants. Mich Acad Sci Arts Lett 1933, 17:119-232.

86. Reagan AB: Plants used by the Bois Fort Chippewa (Ojibwa) Indians of Minnesota. Wisc Archaeol 1928, 7(4):230-248.

87. Smith HH: Ethnobotany of the Ojibwe Indians. Bulletin of the Public Museum of The City of Milwaukee 1932, 4:327-525.

88. Stowe GC: Plants used by the Chippewa. Wisc Archaeol 1940, 21:8-13.

89. Driedger CJ: A journey of a thousand miles begins with a single blueberry: Learning journeys of the Whitefeather Forest, Pikangikum First Nation, Ontario. MSc thesis Natural Resource Institute, University of Manitoba, Winnipeg, Manitoba; 2006.

90. Davidson-Hunt IJ, Jack P, Mandamin E, Wapioke B: Iskatewizaagegan (Shoal Lake) plant knowledge: An Anishinaabe (Ojibway) ethnobotany of northwestern Ontario. J Ethnobiol 2005, 25(2):189-227.

91. Beresford-Kroeger D: Arboretum America: A philosophy of the forest Michigan: The University of Michigan Press; 2003.

92. Marles RJ: The ethnobotany of the Chipewyan of Northern Saskatchewan. Master thesis Department of Biology, University of Saskatchewan, Saskatchewan, Canada; 1984.

93. Siegfried EV: Ethnobotany of the Northern Cree of Wabasca/Desmarais. Master thesis Department of Archaeology, University of Calgary, Alberta, Canada; 1994.

94. Leighton A: A guide to 20 plants and their uses by the Cree Curriculum Resource Unit, Lac La Ronge Indian Band Education, Training and Employment Branch, Saskatchewan; 1983.

95. Leighton AL: Wild plant use by the Woods Cree (Nihïthawak) of EastCentral Saskatchewan. National Museum of Man Mercury Series Ottawa: National Museums of Canada; 1985.

96. Clavelle CM: Ethnobotany of two Cree communities in the southern boreal forest of Saskatchewan. Master thesis Department of Anthropology and Archaeology, University of Saskatchwan, Saskatchwan, Canada; 1997.

97. Smith HI: Materia medica of the Bella Coola and neighbouring tribes of British Columbia. Annual report for 1927 Ottawa: National Museum of Canada; 1927.

98. Lamont SN: The Fisherman Lake Slave and their environment: A story of flora and faunal resources. Master thesis Department of Plant Ecology, University of Saskatchewan, Saskatoon, Canada; 1977.

99. Andre A, Fehr A: Gwich'in ethnobotany: Plants used by the Gwich'in for food medicine, shelter and tools Inuvik, Northwest Territories: Gwich'in Social and Cultural Institute, Tsiigehtchic, and Aurora Research Institute; 2002.

100. Andre A: Nan t'aih nakwits'inahtsih (The land gives us strength): The medicine plants used by Gwich'in people of Canada's western arctic to maintain good health and well being. Master thesis School of Environmental Studies, University of Victoria, British Columbia, Canada; 2006.

101. Ryan J: Traditional Dene medicine. Part one: Report. Lac La Martre, Northwest Territories: Dene Cultural Institute; 1994.

102. Welsh R, Turner NJ: Looking after our elders: Healthcare and well-being of the elderly from the perspective of Gwich'in and other First Nations of Canada. In Alternative medicine and the elderly. Edited by: Cherniack EP, Bronx MD. New York: Springer-Verlag; 2003:287-300.

103. Chandler RF, Hooper SN: Herbal remedies of the Maritime Indians: a preliminary screening. Can J Phar Sci 1979, 14(4):103-106.

104. Wat CK, Johns T, Towers GHN: Phytotoxic and antibiotic activities of plants of the Asteraceae used in folk medicine. J Ethnopharmacol 1980, 2:279-290.

105. Chandler RF, Hooper SN: Herbal remedies of the Maritime Indians: a preliminary screening, Part III. J Ethnopharmacol 1982, 6:275-285.

106. Hooper SN, Chandler RF: Herbal remedies of the Maritime Indians: a preliminary screening, Part II. Can J Phar Sci 1981, 16(1):56-59.

107. Hooper SN, Chandler RF: Herbal remedies of the Maritime Indians: phytosterols and triterpenes of 67 plants. J Ethnopharmacol 1984, 10:181-194.

108. Bergeron C, Marston A, Gauthier R, Hostettmann K: Screening of plants used by North American Indians for antifungal, bactericidal, larvicidal, and molluscicidal activities. Int J Pharmacogn 1996, 34(4):233-242.

109. Owen PL, Johns T: Xanthine oxidase inhibitory activity of northeastern North American plant remedies used for gout. J Ethnopharmacol 1999, 64:149-160. 
110. Jones NP, Arnason JT, Abou-Zaid M, Akpagana K, Sanchez-Vindas P, Smith ML: Antifungal activity of extract from medicinal plants used by First Nations peoples of eastern Canada. J Ethnopharmacol 2000, 73:191-198.

111. Lin LT, Liu LT, Chiang LC, Lin CC: In vitro anti-hepatoma activity of fifteen natural medicines from Canada. Phytother Res 2002, 16:440-444.

112. McCune LM, Johns T: Antioxidant activity in medicinal plants associated with the symptoms of diabetes mellitus used by the indigenous Peoples of the North American boreal forest. J Ethnopharmacol 2002, 82:197-205.

113. McCune LM, Johns T: Symptom-specific antioxidant activity of boreal diabetes treatments. Pharm Biol 2003, 41(5):362-370.

114. McCune LM, Johns T: Antioxidant activity relates to plant part, life form and growing condition in some diabetes remedies. J Ethnopharmacol 2007, 112:461-469.

115. Ficker CE, Arnason JT, Vindas PS, Alvarez LP, Akpagana K, Gbéassor M, De Souza C, Smith ML: Inhibition of human pathogenic fungi by ethnobotanically selected plant extracts. Mycoses 2003, 46:29-37.

116. Bafi-Yeboa NFA, Arnason JT, Baker J, Smith ML: Antifungal constituent of northern Prickly Ash, Zanthoxylum americanum Mill. Phytomedicine 2005 12:370-377.

117. Spoor DC, Martineau LC, Leduc C, Benhaddou-Andaloussi A, Meddah B, Harris C, Burt A, Fraser MH, Coonishish J, Joly E, Cuerrier A, Bennett SA, Johns T, Prentki M, Arnason JT, Haddad PS: Selected plant species from the Cree pharmacopoeia of northern Quebec possess anti-diabetic potential. Can J Physiol Pharm 2006, 84:847-858.

118. Awad R, Levac D, Cybulska P, Merali Z, Trudeau VL, Arnason JT: Effects of traditionally used anxiolytic botanicals on enzymes of the $\gamma^{-}$ aminobutyric acid (GABA) system. Can J Physiol Pharm 2007, 85:933-942.

119. Tsao R, Liu Z: Exploration and characterization of bioactive phytochemicals in native Canadian plants for human health. Can J Plant Sci 2007, 87(5):1045-1053.

120. Webster D, Taschereau P, Belland RJ, Sand C, Rennie RP: Antifungal activity of medicinal plant extracts; preliminary screening studies. $J$ Ethnopharmacol 2008, 115:140-146.

121. Martineau LC, Spoor CA, Vallerand D, Afshar A, Arnason JT, Haddad PS: Enhancement of muscle cell glucose uptake by medicinal plant species of Canada's native populations is mediated by a common, Metforminlike mechanism. J Ethnopharmacol 2009, 127(2):396-406.

122. Chandler RF, Hooper SN, Harvey MJ: Ethnobotany and phytochemistry of Yarrow, Achillea millefolium, Compositae. Econ Bot 1982, 36(2):203-223.

123. Chandler RF, Hooper SN, Hooper DL, Jamieson WD, Lewis E: Herbal remedies of the Maritime Indians: Sterols and triterpenes of Tanacetum vulgare L. Tansy. Lipids 1982, 17(2):102-106.

124. Applequist WL, Moerman DE: Yarrow (Achillea millefolium L.): A neglected panacea? A review of ethnobotany, bioactivity, and biomedical research. Econ Bot 2011, 65:209-225.

125. Dufour D: Évaluation de l'activité biologique du Ledum groenlandicum Retzius. Master thesis Université du Québec à Chicoutimi, Canada; 2006.

126. de Moor V: Étude sur la composition des glycosides du sapin baumier Abies balsamea (L) Mill. Master thesis Université du Québec à Chicoutimi, Canada; 1994

127. Saxena G, McCutcheon AR, Farmer S, Towers GHN, Hancock REW: Antimicrobial constituents of Rhus glabra. J Ethnopharmacol 1994, 42:95-99.

128. Kobaisy M, Abramowski Z, Lermer L, Saxena G, Hancock REW, Towers GHN, Doxsee D, Stokes RW: Antimycobacterial polyynes of Devil's Club (Oplopanax horridus), a North American native medicinal plant. J Nat Prod 1997, 60:1210-1213.

129. Kitts DD, Wizewickreme AN, Hu C: Antioxidant properties of a North American ginseng extract. Mol Cell Biochem 2000, 203:1-10.

130. Vuksan $V$, Sievenpiper $\mathrm{J}$ : Herbal remedies in the management of diabetes: Lessons learned from the study of Ginseng. Nutr Metab Cardiovas 2005, 15:149-160.

131. Murch SJ, KrishnaRaj S, Saxena PK: Tryptophan is a precursor for melatonin and serotin biosynthesis in in vitro regenerated St. John's Wort (Hypericum perforatum L. cv. Anthos) plants. Plant Cell Rep 2000, 19:689-704.

132. Petzke TL, Shi QW, Sauriol F, Mamer O, Zamir LO: Taxanes from rooted cuttings of Taxus canadensis. J Nat Prod 2004, 67:1864-1869.
133. Matsuo Y, Watanabe K, Mimaki Y: Triterpene glycosides from the underground parts of Caulophyllum thalictroides. J Nat Prod 2009, 72:1155-1160.

134. Matsuura H, Saxena G, Farmer SW, Hancock REW, Towers GHN: Antibacterial and antifungal compounds from Empetrum nigrum. Planta Medica 1995, 61(6):580

135. Martineau LC, Couture A, Spoor D, Benhaddou-Andaloussi A, Harris C, Meddah B, Leduc C, Burt A, Vuong T, Le PM, Prentki M, Bennett SA, Arnason JT, Haddad PS: Anti-diabetic properties of the Canadian lowbush blueberry Vaccinium angustifolium Ait. Phytomedicine 2006, 13:612-623.

136. Fraser MH, Cuerrier A, Haddad PS, Arnason JT, Owen PL, Johns T: Medicinal plants of Cree communities (Québec, Canada): Antioxidant activity of plants used to treat type 2 diabetes symptoms. Can J Physiol Phar 2007, 85:1200-1214

137. Harris CS, Lambert J, Saleem A, Coonishish J, Martineau LC, Cuerrier A, Haddad PS, Arnason JT, Steffany AL, Bennett SAL: Antidiabetic activity of extracts from needle, bark, and cone of Picea glauca: organ-specific protection from glucose toxicity and glucose deprivation. Pharm Biol 2008, 46(1-2):126-134.

138. Vianna R, Brault A, Martineau LC, Couture R, Arnason JT, Haddad PS: In vivo anti-diabetic activity of the ethanolic crude extract of Sorbus decora C. K. Schneid. (Rosacea): A medicinal plant used by Canadian James Bay Cree Nations to treat symptoms related to diabetes. Evid-based Compl Alt 2009, $1-8$

139. Anyinam C: Ecology and ethnomedicine: exploring links between current environmental crises and indigenous medicinal practices. Soc Sci Med 1995, 40(3):321-329.

140. Westfall RE, Glickman BW: Conservation of indigenous medicinal plants in Canada. In Proceedings of the Species at Risk 2004 Pathways to Recovery Conference March 2-6, 2004 Edited by: Victoria BC, Hopper TD 2004.

141. Duchesne LC, Zasada JC, Davidson-Hunt I: Non-timber forest product industry in Canada: Scope and research needs. Forest Chron 2000 76(5):743-746.

142. CNR (Centre for Non-timber Resources): Native plants and First Nations: How can we create research that is equitable, sustainable and beneficial to all? Workshop Proceedings and Report Royal Roads University, Victoria, BC, January 24 and 25, 2005 British Columbia: Royal Roads University and Centre for Non-timber Resources; 2005.

143. Karst A: Conservation value of the North American boreal forest from an ethnobotanical perspective Canadian Boreal Initiative, David Suzuki Foundation and Boreal Songbird Initiative; Ottawa, ON; Vancouver, BC; Seattle, WA; 2010.

144. Keefer ME, Ehlers T, Macpherson N: A regional profile of commercial harvesting of non-timber forest products in the Cascade Forest District, British Columbia British Columbia: The Centre for Non-Timber Resources, Royal Roads University; 2008.

145. Marles RJ: Non-timber forest products and aboriginal traditional knowledge. In Forest communities in the third millennium: linking research, business, and policy toward a sustainable non-timber forest product sector. Edited by: Davidson-Hunt I, Duchesne LC, Zasada JC. St. Paul, MN: USDA Forest service, North Central Research Station, Gen. Tech. Rep. NC-217; 2001:

146. Uprety Y, Poudel RC, Asselin H, Boon EK, Shrestha KK: Stakeholder perspectives on use, trade, and conservation of medicinal plants in the Rasuwa District of Central Nepal. J Mt Sci 2011, 8:75-86.

147. Smith P: Aboriginal and treaty rights and Aboriginal participation: Essential elements of sustainable forest management. Forest Chron 1998, 47(3):327-333

148. In Medicinal plants in conservation and development: case studies and lessons learnt. Edited by: Hamilton A. Salisbury, UK: Plantlife International; 2008:

149. Germain R, Asselin H: Zoning of potential for Aboriginal interest: a new decision-support tool in forestry Sustainable Forest Management Network Research Note Series No. 71; 2010.

150. Government of Canada, Species at Risk Public Registry. [http://www. sararegistry.gc.ca].

151. Karjala MK, Sherry EE, Dewhurst SM: Criteria and indicators for sustainable forest planning: a framework for recording Aboriginal resource and social values. Forest Policy Econ 2002, 6:95-110.

152. Usher PJ: Environment, race and nation reconsidered: reflections on Aboriginal land claims in Canada. Can Geogr 2003, 47(4):365-382. 
153. Natcher DC, Hickey CG, Nelson M, Davis S: Implications of tenure insecurity for Aboriginal land use in Canada. Hum Organ 2009, 68:245-257.

154. Natcher DC, Davis S: Rethinking devolution: challenges for Aboriginal resource management in the Yukon territory. Soc Natur Resour 2007, 20:271-279.

155. CBD (Convention on Biological Diversity): Convention on Biological Diversity. 1992 [http://www.biodiv.org/convention/convention.shtml\#].

156. Schippmann $U$, Cunningham $A B$, Leaman DJ: Impact of cultivation and gathering of medicinal plants on biodiversity: Global trends and issues. Biodiversity and the ecosystem approach in agriculture, forestry and fisheries Rome: FAO; 2002 [http://www.fao.org/DOCREP/005/Y4586E/y4586e08.htm]

157. Chandrasekharan C: Terminology, definition and classification of forest products other than wood. Report of the International Expert Consultation on Non-Wood Forest Products Yogyakarta, Indonesia. 17-27 January 1995. Non-wood forest products No. 3. Rome: FAO; 1995, 345-380.

158. Wiersum KF, Dold AP, Husselman M, Cocks M: Cultivation of medicinal plants as a tool for biodiversity conservation and poverty alleviation in the Amatola region, South Africa. In Medicinal and aromatic plants. Edited by: Bogers RJ, Craker LE, Lange D. Springer; 2006:.

159. Timmermans $\mathrm{K}$ : Intellectual property rights and traditional medicines: policy dilemmas at the interface. Soc Sci Med 2003, 57:445-456.

160. UNEP (United Nations Environmental Program), CBD (Convention on Biological Diversity): Report of the Tenth Meeting of the Conference of the Parties to the Convention on Biological Diversity 2010 [http://www.cbd.int/ doc/meetings/cop/cop-10/official/cop-10-27-en.pdf].

161. UN (United Nations): United Nations Declaration on the Rights of Indigenous Peoples 2008 [http://www.un.org/esa/socdev/unpfii/documents/DRIPS_en. pdf].

162. WHO (World Health Organization): Report of the consultation to review the draft guidelines for the assessment of herbal medicines, Munich, Germany Geneva: World Health Organization; 1991 [http://whqlibdoc.who.int/hq/ 1991/WHO_TRM_91.3.pdf].

163. WHO (World Health Organization): Guidelines for the assessment of herbal medicines Geneva: World Health Organization; 1992 [http://whqlibdoc.who. int/HQ/1991/WHO TRM 91.4.pdf].

164. WHO (World Health Organization): Indigenous people and participatory health research Geneva: World Health Organization; 2003.

165. WHO, IUCN, WWF: Guidelines on the conservation of medicinal plants Gland, Switzerland: The World Conservation Union (IUCN), in partnership with The World Health Organization (WHO) and World Wide Fund for Nature (WWF); 1993.

166. FAO (Food and Agriculture Organization of the United Nations): In Domestication and Commercialization of Non-timber Forest Products in Agroforestry Systems. Volume 9. FAO, Non-Wood Forest Products; 1996:5-24.

167. International Healers Conference, Bangalore, India. [http://www. healersexchange.org].

168. Marggraf R: Global conservation of biodiversity from an economic point of view. In Valuation and conservation of biodiversity: Interdisciplinary perspectives on the Convention on Biological Diversity. Edited by: Markussen M, Buse R, Garrelts H, Manez Costa MA, Menzel S, Marggraf R. Springer; 2005:3-21

169. CCFM (Canadian Council of Forest Ministers): A National Forest Sector Strategy for Canada Ottawa: Canadian Council of Forest Ministers; 1988.

170. McGregor D: Aboriginal/non-Aboriginal relations and sustainable forest management in Canada: the influence of the Royal Commission on Aboriginal peoples. J Environ Manage 2011, 92(2):300-310.

171. Canada's Statement of Support on the United Nations Declaration on the Rights of Indigenous Peoples, Aboriginal Affairs and Northern Development Canada. [http://www.aadnc-aandc.gc.ca/eng/ 1309374239861].

172. CCFM (Canadian Council of Forest Ministers): Sustainable Forests: A Canadian Commitment Quebec: Hull; 1992

173. Government of Canada: Species at Risk Act 2002 [http://www.parl.gc.ca/37/ 1/parlbus/chambus/house/bills/government/C-5/C-5_3/C-5_cover-E.html].

174. Moss K, Boon H, Ballantyne P, Kachan N: New Canadian natural health product regulations: A qualitative study of how CAM practitioners perceive they will be impacted. BMC Complem Altern M 2006, 6:18.

175. Agricultural and Agri-Food Canada: Canada's medicinal plants industry: a profile. 2007 [http://www.agr.gc.ca/].
176. Tikina AV, Innes $J$, Trosper RL, Larson BC: Aboriginal peoples and forest certification: A review of the Canadian situation. Ecol Soc 2010, 15(3):33.

177. Collier R, Parfitt B, Woollard D: A Voice on the Land: An Indigenous Peoples' Guide to Forest Certification in Canada Canada: National Aboriginal Forestry Association and Ecotrust Canada; 2002.

178. Trotter RT, Logan MH: Informant consensus: a new approach for identifying potentially effective medicinal plants. In Plants in indigenous medicine and diet: Biobehavioural approaches. Edited by: Etkin NL. Bedford Hill, New York: Redgrave Publisher; 1986:91-112.

179. Höft M, Barik SK, Lykke AM: Quantitative ethnobotany: applications of multivariate and statistical analyses in ethnobotany. People and Plants working paper 6 Paris: UNESCO; 1999.

180. Begossi A, Hanazaki N, Tamashiro JY: Medicinal plants in the Atlantic Forest (Brazil): knowledge, use, and conservation. Hum Ecol 2002, 30(3):281-299.

181. Araujo TAdS, Alencar NL, de Amorim ELC, de Albuquerque UP: A new approach to study medicinal plants with tannins and flavonoids contents from the local knowledge. J Ethnopharmacol 2008, 120:72-80.

182. Newmaster SG, Ragupathy S: Ethnobotany genomics - discovery and innovation in a new era of exploratory research. J Ethnobiol Ethnomed 2010, 6:2.

183. Darcy PF: Adverse reactions and interactions with herbal medicines. 1. Adverse reactions. Adverse Drug React Toxicol Rev 1991, 10(4):189-208.

184. Darcy PF: Adverse reactions and interactions with herbal medicines. 2. Drug-interactions. Adverse Drug React Toxicol Rev 1993, 12(3):147-162.

185. Izzo AA, Ernst E: Interactions between herbal medicines and prescribed drugs: An updated systematic review. Drugs 2009, 69(13):1777-1798.

186. Kumar CD: Pharmacognosy can help minimize accidental misuse of herbal medicine. Curr Sci India 2007, 93(10):1356-1358.

187. Alves RRN, Rosa IL: Why study the use of animal products in traditional medicines? J Ethnobiol Ethnomed 2005, 1:5.

188. Holliday I: Traditional medicines in modern societies: An exploration of integrationist options through East Asian experience. J Med Phil 2003, 28(3):373-389.

189. Giordano J, Garcia MK, Strickland G: Integrating Chinese traditional medicine into a US public health paradigm. J Altern Complem Med 2004 10:706-710.

190. Shaikh BT, Hatcher J: Complementary and alternative medicine in Pakistan: prospects and limitations. Evid-based Compl Alt Med 2005, 2(2):139-142

191. Giovannini P, Heinrich M: Xki yoma' (our medicine) and xki tienda (patent medicine) - Interface between traditional and modern medicine among the Mazatecs of Oaxaca, Mexico. J Ethnopharmacol 2009, 121:383-399.

192. Lim B, Park J, Han C: Attempts to utilize and integrate traditional medicine in North Korea. J Alt Complem Med 2009, 15(3):217-223.

doi:10.1186/1746-4269-8-7

Cite this article as: Uprety et al:: Traditional use of medicinal plants in the boreal forest of Canada: review and perspectives. Journal of Ethnobiology and Ethnomedicine 2012 8:7.

\section{Submit your next manuscript to BioMed Central and take full advantage of:}

- Convenient online submission

- Thorough peer review

- No space constraints or color figure charges

- Immediate publication on acceptance

- Inclusion in PubMed, CAS, Scopus and Google Scholar

- Research which is freely available for redistribution

Submit your manuscript at www.biomedcentral.com/submit
C Biomed Central 